\title{
EL JUICIO DE SÓCRATES DESDE EL PUNTO DE VISTA ATENIENSE
}

\author{
Mogens Herman Hansen* \\ doi:10.11144/Javeriana.uph33-67.jsva
}

\begin{abstract}
RESUMEN
Este estudio reconstruye el juicio de Sócrates, especialmente, el caso levantado por los acusadores. La primera parte es una discusión sobre las fuentes que tenemos disponibles para reconstruir el juicio, especialmente el análisis de Jenofonte en Memorabilia. La segunda parte reconstruye el juicio basados en una nueva evaluación de las fuentes. La tercera parte discute los aspectos políticos del juicio, y argumenta que haber levantado acusaciones políticas contra Sócrates no era necesariamente una infracción a la amnistía del 403. Más aún, un estudio prosopográfico del círculo social alrededor de Sócrates muestra que un alto número de sus "amigos" eran ciudadanos que se habían unido a la revolución oligárquica del 411 y del 404-403 y habían sido condenados por traición y/o impiedad. Finalmente, se presenta un diálogo pseudo-platónico entre Sócrates y Ánito en el que Sócrates tiene que admitir que la democracia es la mejor constitución posible.

Palabras clave: juicio de Sócrates; Platón; Jenofonte; democracia; Atenas
\end{abstract}

* Universidad de Copenhague, Copenhague, Dinamarca.

Correo electrónico: mhh@hum.ku.dk

La presente traducción al castellano, realizada por Joaquín Garzón Vargas, Pontificia Universidad Javeriana (Bogotá Colombia), procede de la monografía en inglés: Hansen, M.H. (1995). The Trial of Socrates - from the Atenian Point of View. Copenhagen: Royal Danish Academy of Sciences and Letters. El traductor agradece especialmente los aportes de Ana María Pulido, Pablo Gómez, Jorge Gil, María Alejandra Solano y del profesor Franco Alirio Vergara quien, como tutor del Semillero de investigación "Cuestiones sobre la Justicia" de la Facultad de Filosofía de la Pontificia Universidad Javeriana de Bogotá, presentó el texto original y ha guiado a los miembros del semillero en el camino de la filosofía.

Para citar este artículo: Hansen, M.H. (2016). El juicio de Sócrates desde el punto de vista ateniense. Universitas Philosophica, 33(67), pp. 17-52. ISSN 0120-5323, ISSN en línea: 2346-2426, doi:10.11144/Javeriana.uph33-67.jsva 


\title{
THE TRIAL OF SOCRATES FROM THE ATHENIAN POINT OF VIEW
}

\author{
Mogens Herman Hansen
}

\begin{abstract}
This study reconstructs the trial of Socrates, especially, the case raised by the accusers. The first part discusses the sources, in particular, the evaluation by Xenophon's Memorabilia. The second part of the study reconstructs the trial based on a new assessment of sources. The third part discusses the political aspects of the trial, arguing that having raised political accusations against Socrates was not necessarily a violation of the amnesty of 403. Moreover, a prosopographical study of the social circle around Socrates shows that a high number of his "friends" were citizens who had joined the oligarchic revolution 411 and 404-403 and had been convicted of treason and / or impiety. Finally, a pseudo-Platonic dialogue between Socrates and Anytus in which Socrates has to admit that democracy is the best constitution is presented.
\end{abstract}

Key words: the trial of Socrates; Plato; Xenophon; democracy; Athens 
Introducción

EN EL 399 A.C Sócrates, EL FILÓsofo, fue condenado a muerte y ejecutado por los atenienses por el cargo de impiedad. Años después, su pupilo, Platón, publica un ensayo que pretendía ser el discurso de defensa de Sócrates. A través de la apología de Platón, Sócrates había ganado el título de mártir. En la historia de la filosofía occidental, la ejecución de Sócrates está representada como un asesinato judicial: el intento de los atenienses de acallar la propia voz de su conciencia por medio de la ejecución del más noble e inteligente entre ellos. Sócrates estaba en el centro de la atención y la Apología de Platón parecía ser una legítima defensa de su causa sin importar la veracidad histórica de su reporte. Centraré mi atención en los tres (3) acusadores y los quinientos un (501) jurados que condenaron a Sócrates a muerte. ¿Fue el juicio de Sócrates una deshonra para la democracia ateniense o, quizás, un tratamiento comprensible e incluso justificable de alguien que representaba una amenaza para la constitución ateniense? Mi aproximación no dista mucho de la de I.F Stone en The Trial of Socrates (1989). Sin embargo, aunque el libro de Stone está cargado de malinterpretaciones de las fuentes por la omisión de piezas importantes de información sobre el juicio y su mirada hostil frente a Sócrates, creo que ese estudio no es anulado por este libro; más bien, puede entenderse como una corrección a las reconstrucciones del juicio descritas en él ${ }^{1}$.

\section{Las fuentes}

DADO QUE SOY HISTORIADOR, ANTES QUE FILÓSOFO, empezaré por examinar las fuentes.

La Apologia de Platón es una fuente contemporánea con el suceso ya que probablemente fue escrito una década después del juicio². Además de esto, es el

1 Mi visión sobre el juicio de Sócrates se remonta a mi artículo en danés de 1980. Hice un resumen de mi investigación al ser invitado a presentar un artículo en el simposio llevado a cabo en Atenas en noviembre de 1922 para la celebración de los 2500 años de la democracia. El simposio fue organizado por la Academia Ateniense y su presidente el profesor Michel Sakellariou. A pesar de su muy eficiente gestión, la publicación de las memorias de este simposio ha sido demorada por lo que estoy profundamente agradecido con él por haberme permitido publicar mi contribución en esta forma.

2 Remítase al apéndice 1 al final del documento. 
reporte de un testigo ocular, pues Platón alega haber asistido al juicio de Sócrates y haber estado entre los que ofrecieron pagar una fianza por él. Por otro lado, nos enfrentamos a dos problemas con este texto: primero, que Platón no es imparcial ya que defiende a Sócrates en vez de, simplemente, narrarnos los acontecimientos. Segundo, Platón es un poeta, lo que es peor, ya que no podemos descartar la posibilidad de que la Apología sea una ficción y no el reporte de la realidad ${ }^{3}$.

Debemos enfrentarnos a dos problemas: (a) La Apología es esencialmente un relato fiel a lo que Sócrates dijo en realidad en la corte. Incluso suponiendo esto, aún tenemos que enfrentar otro problema: (b) podemos haber pasado por alto cargos importantes traídos por los acusadores a causa del silencio de Sócrates frente a ellos en su defensa o algunos de los cargos discutidos en la Apología podrían haber sido tergiversados por Sócrates en su discurso. ¿Cómo podremos saber si la visión de Platón acerca de su amado maestro es un recuento fiel a la vida y obra de Sócrates? La única manera de juzgar a la defensa es reconstruir los argumentos de los acusadores. El historiador está en la misma posición de los jueces. Es imposible saber la verdad y dar un veredicto sin haber oído las dos partes del caso.

Aparte de la Apología de Platón, ¿̇cuáles fuentes hay disponibles para conocer más del juicio de Sócrates? Existen muchas pero, lamentablemente, la mayoría hace lo que hace Platón: defender a Sócrates.

Las fuentes en cuestión son la Apología de Jenofonte ${ }^{4}$ y los primeros dos capítulos del primer libro de su Memorabilia ${ }^{5}$. Luego, la Apologia Sokratous ${ }^{6}$ de Libanio y, finalmente, dos tratados perdidos: una Apología de Lisias (de las cuales solo sobrevivieron 4 fragmentos inútiles para nuestros propósitos) ${ }^{7}$ y una Apologia de Demetrio de Falero (de esta llegaron a nosotros seis fragmentos) ${ }^{8}$.

3 Remítase al apéndice 2 al final de este documento.

4 Largas secciones de la Apología están repetidas literalmente en Memorabilia 4.8.1-11.

5 La Memorabilia de Jenofonte ha sido fechada tradicionalmente en el 360s. Ver: Simeterre,1938, p. 13. Una hipótesis más compleja de la Memorabilia es que comienza en 1.3 y que una versión más temprana de la defensa de Sócrates (1.1-2) fue añadida después como una especie de introducción al Libro 1. Sobre esto, ver: Chroust, 1957, pp. 44-68.

6 Declamatio 1.

7 Fragmento 220-24.

8 Fragmento 91-8. 
Tengo los siguientes comentarios que hacer frente a los cuatro documentos disponibles. En la Apología de Platón, el mito de que el tratado es un discurso forense, es sostenido a través de todo el documento. Es importante reparar en que Platón omitió incluso la introducción más típica: "El otro día me encontré con $\mathrm{NN}$ en el Ágora y dijo que recientemente asistió a un diálogo entre Sócrates y X en el que Sócrates discutió los siguientes argumentos...". La razón de esta omisión pudo haber sido que Platón estuvo presente en la corte cuando Sócrates pronunció su discurso (Platón, Apol. 38b).

La Apología de Jenofonte no es ficción como la de Platón. Solamente la parte central (11-21) pretende ser la defensa de Sócratese incluso solo esta es un resumen narrado en el estilo indirecto. La primera y la tercera parte son el relato de Jenofonte sobre el juicio.

En la Memorabilia de Jenofonte no hay ni siquiera un recuento de lo que Sócrates dijo en su defensa. Se trata de la apología de Jenofonte en favor de Sócrates en lugar de la defensa de este último. Por el otro lado, esta fuente incluye un resumen de algunos de los cargos presentados contra Sócrates (Mem.1.29, 12, 49, 56) seguidos -no por el discurso de Sócrates-sino por la refutación de dichos cargos hecha por Jenofonte, quien alega que estos eran absurdos e injustificados.

En Libanio es ampliamente sostenido el mito de la existencia de un discurso realizado para la defensa. Sin embargo, dicho discurso no es atribuido a Sócrates sino a uno de sus synegoroi. Más allá de esto, mientras la defensa de Platón y Jenofonte están dirigidas a Meleto, el discurso de Libanio (Decl. 1.2, 4-5 ss) es una respuesta a Ánito, y una parte considerable del discurso está dedicada a refutar los cargos políticos. De cualquier forma, el discurso de Libanio es considerablemente tardío y fue escrito por un autor especializado en transformar casos históricos en discursos forenses ficticios.

Las fuentes principales son, entonces, la Apología de Platón y la narración del juicio de Jenofonte en los dos primeros capítulos del primer libro de su Memorabilia. Al comparar las narraciones de Platón y Jenofonte debería ser posible juzgar si la defensa pronunciada por Sócrates puede reconstruirse. Hay por supuesto muchas diferencias entre la descripción ofrecida por el poeta que filosofa y el coronel exiliado; sin embargo, también hay similitudes sorprendentes. Veamos: 
1. La defensa de Sócrates se dirige solo a Meleto y pasa por alto los cargos imputados por Licón y Ánito.

2. Sócrates no había preparado formalmente un discurso para su defensa (Platón, Apol., 17c-18a; Jenofonte, Apol., 3)

3. Meletos es contrainterrogado (Platón, Apol., 24c-27d; Jenofonte, Apol., 19-21).

4. Sócrates habla de la vejez y declara que a su edad es más digno morir que llevar una existencia miserable (Platón, Apol., 38c, 41d; Jenofonte, Apol., 1, 6-9, 23, 27, 32-3).

5. El Daimonion de Sócrates insinúa que daimones tiene que existir por lo que, de nuevo, insinúa la creencia en la existencia de los dioses (Platón, Apol., 27a-28a; Jenofonte, Apol., 10-3; Mem. 1.1.4-5).

6. Sócrates niega y refuta tener cualquier interés serio en la filosofía natural (Platón, Apol., 26d; Jenofonte, Mem. 1.1.11-5).

7. Sócrates evoca su comportamiento constitucional durante el juicio de los generales cuando, presidiendo la asamblea, se rehusó a someter a votación una propuesta inconstitucional (Platón, Apol., 32b; Jenofonte, Mem., 1.1.18).

8. La respuesta del oráculo délfico a Querefonte es evocada y explicada (Platón, Apol., 20e-23b; Jenofonte, Apol., 14-15)9.

9. Después de la sentencia, Sócrates se rehúsa a proponer lo que los jurados podrían aceptar como una penalidad apropiada (Platón, Apol., 36b38b; Jenofonte, Apol., 23).

10. Después de ser condenado a muerte, Sócrates pronuncia un discurso sobre el significado de la muerte para un hombre (Platón, Apol., 38c-42a; Jenofonte, Apol., 24-26).

De estos diez puntos puedo inferir que las descripciones de Platón y Jenofonte se parecen, pues tanto el uno como el otro provienen de una fuente común. Concuerdo con von Arnim en que Jenofonte no había leído la Apología de Sócrates cuando escribió su narración ${ }^{10}$ por lo que tampoco hay razón para creer

9 Véase: Fontenrose,1978, pp. 34-5,245.

10 Ver apéndice 1. 
que Platón haya sido influenciado por la descripción de Jenofonte. Platón asistió al juicio (Platón, Apol., 38b) por su cuenta y Jenofonte obtuvo la información de Hermógenes, el hijo de Hipónico, amigo de Sócrates (Jenofonte, Apol., 2). Hermógenes estuvo, a su vez, presente en la prisión cuando Sócrates fue ejecutado (Platón, Fedón, 59b). No encuentro ninguna razón para dudar de la veracidad de la información expuesta por Jenofonte sobre su fuente. Parece ser que la conclusión es que las versiones de Jenofonte y Platón son muy similares porque ambas cuentan lo que en efecto sucedió en el año 399.

Todo esto a propósito de la defensa. Pero ¿qué tanto sabemos de los acusadores? Además del contrainterrogatorio de Sócrates a Meleto reportado por Jenofonte y Platón, tenemos cuatro fuentes adicionales:

1. Información prosopográfica de los tres acusadores.

2. Algunas citas de un discurso contra Sócrates, hoy perdido, por el orador Polícrates (fragmento VIII, pp. 10-11).

3. Seis cargos específicos contra Sócrates reportados por Jenofonte en su Memorabilia y todos introducidos con la frase ó $\kappa a \tau \eta \dot{\gamma} \gamma o p o s \varepsilon ै \phi \varepsilon$, "el acusador dijo que..." (Jenofonte, Mem., 12.9, 12, 49, 51, 56, 58).

4. La acusación a Sócrates, citada en su totalidad por Diógenes Laercio y parcialmente por Jenofonte y Platón. Diógenes dice haber encontrado el texto en un libro de Favorinus, quien a su vez afirma haber visto el original en un archivo público de Atenas (Diógenes Laercio, 2. 40).

Re1: Además de Meleto, quien fue el acusador principal, otras dos personas figuraban en el bando acusador como syngoroi: Licón, quien no ha podido ser identificado con ningún otro personaje de la época con ese nombre ${ }^{11}$, y Ánito, bien conocido por otras fuentes. Él era un líder político prominente y democrático que había estado en la corte unos meses antes del juicio de Sócrates, a saber: en el juicio de Andócid es por el cargo de impiedad elevado ante los jueces en el otoño del $400^{12}$. No obstante, en este juicio él se encontraba entre los que apoyaban a la defensa. La razón es que el juicio de Andócides estaba basado en la

11 Ver apéndice 3.

12 Al respecto, véase: Andócides, I. 150; Kircher,PA 1324; MacDoweel, 1962, p. 166; Davies, 1971, pp. $40-41$. 
profanación de los Misterios en el 415. Pero en el 403 los atenienses les concedieron a todos (con excepción de los líderes oligarcas) amnistía absoluta por ofensas del pasado ${ }^{13}$. Ánito era conocido por estar entre los líderes políticos que respetaban la amnistía y rechazaba cualquier violación a la misma (Isócrates, 18. 23).

Por lo que sabemos sobre Ánito, se ha podido inferir frecuentemente que los acusadores no pueden haber levantado cargos políticos contra Sócrates. En pri-

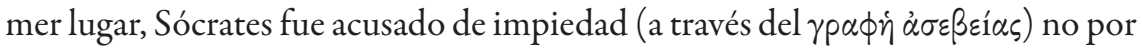
haber saboteado la democracia ( $\kappa \alpha \tau \dot{\alpha} \lambda \nu \sigma ı \varsigma \tau o \tilde{\delta} \delta \dot{\eta} \mu о v)$. En segundo lugar, Ánito nunca hubiera respaldado a los acusadores en la corte si el veredicto hubiera tenido como consecuencia la infracción de la amnistía. Esta línea de argumentación es poco convincente pero volveré a esto después.

Re2: Se nos ha dicho que Polícrates (Fragmento VII), el retórico, escribió un discurso para la acusación de Sócrates. Algunas fuentes sostienen que el discurso en efecto fue pronunciado en el 399, durante el juicio ${ }^{14}$. Sin embargo, esta visión es acertadamente rechazada por Favorinus (Diógenes Laercio, 2. 39), quien argumenta que Polícrates se refiere a la reconstrucción de Conón (en el 393) de los muros alrededor de Atenas (Jenofonte, Helénicas, 4.8.10; Dem., 20.68ff). Por lo anterior, el panfleto de Polícrates no pudo haber sido la publicación del discurso dado en el 399, como tampoco puede haber sido una ficción, como la Apología de Platón. Tuvo que haber sido un ensayo como la Apología de Jenofonte que incluye un resumen del discurso de Sócrates y una discusión sobre todo el juicio. Jenofonte (Apol., 31) se refiere, por ejemplo, a la muerte de Ánito.

Además de la reconstrucción de Conón de los muros alrededor de Atenas, lo único que sabemos del presunto discurso para los acusadores de Polícrates (Isócrates, 11.5) es que declaró que Alcibíades era un pupilo de Sócrates. También que él citó ese pasaje en la Ilíada en el que Odiseo es descrito como una persona que trata a los aristócratas de manera educada y a los plebeyos con arrogancia y altivez ${ }^{15}$. Así que reconstruir la acusación es más difícil que reconstruir la

13 Ver: Aristóteles, Constitución de los atenienses, 39.6; Andócides, 1.87, 90; Jenofonte, Helénicas,2.4.43; Aristófanes, Plut., 1146; Aeschin, 2.176; Loening, 1987).

14 Ver: Claudio Eliano, Var. Hist., 5.11.10; Quint,2.17.4; Temistio, xxiii,p.375; Isócrates, 11; Suda, s.v

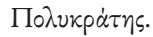

15 Ver: Homero, Iliada, 2.2.188ff. Escolio en Aristides $\dot{v} \pi \dot{\varepsilon} \rho \tau \tilde{\omega} v \tau \varepsilon \tau \tau \dot{\alpha} \rho \omega \nu$ 133.16, 3.480. 
defensa. Primero, el panfleto de Polícrates está perdido. Segundo, no sabemos hasta qué punto el panfleto reproducía lo dicho en el año 399.

Algunos académicos afirman que la reconstrucción del panfleto de Polícrates puede hacerse con la Memorabilia de Jenofonte y la Apología de Libanio, pero la reconstrucción de estas líneas está destinada a caer como un castillo de naipes. Aquellos que usan la Apología de Libanio para reconstruir el discurso perdido de Polícrates proceden argumentativamente de la siguiente forma. Primera premisa: las fuentes que (erróneamente) sostienen que el discurso de Polícrates fue dado en el 399 consideran que fue escrito por Ánito (Chorust, 1957, pp. 69100; Vlastos, 1983, p. 503; Brickhouse \& Smith, 1989, p. 4, 72; Stone, 1989, p. 28). Segunda premisa: la Apología de Libanio apunta a Ánito (Temistio, xxiii; Hypoth. Isoc., 11 ${ }^{16}$. Conclusión: el discurso de Libanio tiene que ser una respuesta del ataque de Polícrates a Sócrates (Choroust, 1957, p. 74 nota 410).

Sin embargo, es inadmisible sostener esta línea de argumentación. Si las fuentes son incorrectas en cuanto a las fechas del discurso de Polícrates, estarán igual de equivocadas en cuanto a la conexión de Polícrates y Ánito. Es relevante recordar que las intervenciones de los acusadores eran por lo general anónimas, en tanto que el orador no revela su nombre durante el discurso. Es un mal método rechazar la primera parte de una declaración y después aceptar la segunda sin ninguna evidencia complementaria. Finalmente, la referencia del trabajo de Konon en Polícrates indica que no hubo un discurso propiamente dicho, sino un ensayo, como la Apología de Jenofonte.

El argumento basado en la Memorabilia de Jenofonte se explica de la siguiente manera. Un número de secciones son introducidas con la frase $\dot{o}$

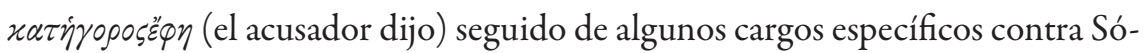
crates y la indignante refutación de Jenofonte de unos cargos sobre esta. Estos importantes pasajes son dejados de lado porque, se ha dicho que hokatogoros no se refiere a los acusadores del 399 como tal, sino al panfleto de Polícrates ${ }^{17}$; ade-

16 El discurso de Polícrates escrito por ambos Meleto y Ánito.

17 La identificación de ó xatíropos con Polícrates devuelve a Cobet (1858, pp. 662-682). La mayoría de los argumentos lingüísticos y prosopográficos de Cobet fueron refutados por Breitenbach (1869, pp. 801-815). No obstante, la identificación de Cobet ganó terreno y ahora es universalmente aceptada. 
más, porque los cargos en el panfleto de Polícrates tienen que haber sido considerablemente diferentes a lo que fue efectivamente dicho en el juicio.

De nuevo, en este punto, la versión tradicional es difícilmente sostenible y urge que sea revisada. La prueba de que Jenofonte tenía que estar haciendo referencia a Polícrates y no a uno de los acusadores se desarrolla así: (a) Isócrates narra que, de acuerdo con Polícrates, Alcibiades era un discípulo de Sócrates. De manera similar, el acusador afirma, en la Memorabilia de Jenofonte (1.2. 12; Isócrates, 11.5), que Sócrates había sido el maestro de Crítrio y Alcibiades. (b) En los escolios de Arístides, su discurso "A Platón, en defensa de los cuatro", se dice que Polícrates en su panfleto contra Sócrates citó aquellas líneas de la Ilíada (2. $188 \mathrm{ff})$ en las que Odiseo es descrito como una persona que trata a los aristócratas de manera educada y a los plebeyos con arrogancia y altivez. Sin embargo, el acusador en la Memorabilia (1.2.58) de Jenofonte se refiere al mismo pasaje. De cualquier manera estos dos argumentos (Chroust, 1957, p. 72) no son suficientes para probar la suposición que el kategoros de Jenofonte tenía que ser Polícrates y no cualquier otro acusador. Hay otras dos reconstrucciones igualmente posibles de las relaciones entre las fuentes:

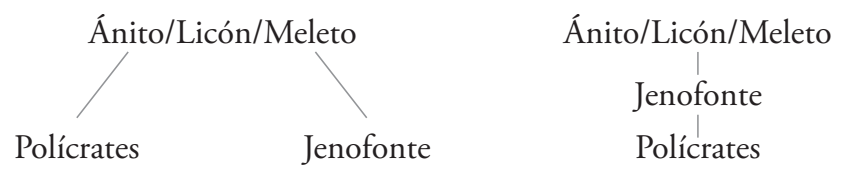

Estos dos modelos son rechazados generalmente por la siguiente línea de pensamientos. Cuando la democracia fue reinstaurada en el 403, los atenienses decidieron el conflicto civil con una amnistía general por todos los crímenes políticos. En el 399, imputarle un cargo político a Sócrates hubiera sido una infracción a la amnistía. Ahora bien, el más influyente entre los acusadores de Sócrates es conocido por haber sido un vehemente defensor de la amnistía. Sin embargo, dos de los cargos imputados por Jenofonte son acusaciones políticas: Sócrates habría socavado la constitución democrática con sus discusiones subversivas y, además, habría sido el maestro de Crítios y Alcibiades. Ánito nunca hubiera permitido la imputación de esos cargos en el 399 y, en consecuencia, los cargos políticos deberían ser el centro del panfleto de Polícrates y no del juicio (Chroust, 1957, p. 73). 
No obstante, este argumento está basado en una mala interpretación de la amnistía. Primero, la amnistía no contemplaba solo crímenes políticos, sino ofensas de cualquier índole, incluida la impiedad. Segundo, la amnistía consistía en asegurar el perdón de cualquier crimen cometido antes del 403 (Cloché, 1915, pp. 251-277; Loening, 1987, p. 100); esto significa que cualquier persona podía ser considerada responsable por cualquier crimen después del 403 (Stone, 1988, pp. 154-155).

Re3: Los dos cargos contra Sócrates registrados por la Memorabilia (1.2.9) de Jenofonte son los siguientes: (1) Sócrates induce a aquellos con los que conversa a desdeñar las leyes, calificando de locura el sorteo para escoger a los magistrados, puesto que nadie estaría dispuesto a elegir un timonel, un arquitecto o incluso un profesor de música de la misa forma. Sin embargo, las equivocaciones en estos asuntos serían mucho menos fatales que los errores que conciernen a la polis. En los jóvenes estos argumentos suscitan desdén y los hacen ponerse violentos. (2) Sócrates fue asociado a Critias y Alcibiades quienes ocasionaron los desastres más grandes de la ciudad (Jenofonte, Mem., 1.2.12).

Tomemos la primera página: Sócrates era famoso o, más bien, de mala reputación, por decir siempre lo mismo sobre la misma cosa y en la misma forma (Platón, Gorg., 490e; Jenofonte, Mem., 4. 4. 6). Es increíble que en el 403 Sócrates haya dejado de decir y pensar que era una estupidez elegir a los magistrados por sorteo. No cabe duda que en la discusión continuó diciendo lo mismo frente a este asunto, incluso en el juicio en el 399. Entonces, Sócrates pudo haber sido acusado de criticar las instituciones democráticas en el periodo del 403-399 sin ninguna violación a la amnistía.

Luego, es cierto que la amnistía protegía a Sócrates de haberse asociado con Critias y Alcibiades, lo que no significa que el acusador se viera impedido de mencionar la relación previa con estos siniestros personajes. El cargo podía imputarse con la intención de referirse a lo ocurrido después del 403; sin embargo, también habrían podido hacer referencia a los acontecimientos previos a $403 \mathrm{sin}$ infringir la amnistía en modo alguno (Vlastos, 1983, p. 497). Consideren, por ejemplo, lo siguiente: "Incluso después de la amnistía Sócrates continúa diciendo que es estúpido usar el sorteo para la elección de los magistrados. Estas discusiones socavan la democracia y han resultado ya dos veces en revoluciones oligárquicas. Recuerdo lo que pasó cuando Sócrates discutió con Critias y 
Alcibiades. Si le permitimos a Sócrates seguir como va, terminaremos en otra revolución Oligárquica" ${ }^{18}$. En este sentido, una argumentación sería impecable desde el punto de vista legal y de la lógica. Si buscamos un ejemplo similar podemos recurrir al discurso de Lisias contra Nicómaco. Él estaba a cargo de la codificación de las leyes entre el 410 y el 399. En el 399 fue llamado a rendir cuentas por lo que hizo entre el 403 y el 399, pero el acusador para quien Lisias escribió un discurso no deja de mencionar las actividades de Nicómaco en el comité legislativo entre el 410 y el 404 (Lisias, 30.2-4). A propósito, es interesante notar que el juicio de Nicómaco gira alrededor de los mismos dos cargos imputados a Sócrates: la subversión de la democracia (al hacer un mal uso de la codificación) y la impiedad (por haber cambiado algunas de las leyes que regulaban los sacrificios tradicionales) ${ }^{19}$.

De cualquier manera, otros dos argumentos han sido traídos a colación contra la hipótesis de que el acusador de Jenofonte mencionara a alguno de los acusadores en el 399 y no a Polícrates.

Primer Argumento: Sócrates fue efectivamente acusado de impiedad y llevado a juicio a través del graphe asebeias. El carácter de la formulación de los cargos va en contra de la suposición de que también haya sido acusado de tener visiones antidemocráticas.

Segundo argumento: los cargos políticos fueron dejados de lado por Platón y Jenofonte en sus apologías y son traídos a colación solo en la Memorabilia. Es poco probable que los cargos importantes discutidos en el juicio hayan dejado de ser mencionados en ambas apologías.

Respecto al primer argumento: es cierto que a Sócrates le fue imputado el cargo de asebeia, lo cual no descarta que también lo hayan acusado de cometer ofensas políticas. Aquí estamos siendo enfrentados a una de las diferencias fundamentales entre la administración de la justicia antigua y moderna. En la sociedad moderna, cuando un hombre es llevado a juicio puede ser acusado de cometer diferentes ofensas en diferentes momentos y actos, y estos cargos serán discutidos en un mismo juicio. Los atenienses tenían múltiples tipos de acciones

18 En el texto original no hay referencia de esta cita, al parecer se trata de un fragmento o cita indirecta de Memorabilida de Jenofonte. (N. del T.)

19 Ver: sobre la impiedad: Lisias, 30.19-21; sobre la subversión de la democracia: Lisias, 30.9 \& 30. 
y había mínimo un procedimiento por cada ofensa, a veces más de uno (Lipsius, 1905-1915, pp. 237-268). Es por esto que una persona que había cometido más de una ofensa era llevado múltiples veces a juicio para ser juzgado de acuerdo con los diferentes tipos de acción ${ }^{20}$. En consecuencia, un ateniense a quien se le imputara el cargo de impiedad, solo podía ser juzgado por impiedad; esto, sin embargo, no les impedía a los acusadores mencionarles a los jueces todos los otros crímenes de los que el acusado era culpable. En todas las intervenciones preservadas de los acusadores atenienses, a los defendidos se les acusa de muchas más ofensas de las que son imputadas en un juicio específico. Después de la audiencia, los jurados presentaban un veredicto de culpable o no. Por lo mismo, el defendido no era absuelto o condenado del cargo específico que se la había imputado ya que los jueces habían sido influenciados por todas las demás ofensas, las cuales, siendo estrictos, eran irrelevantes. Entonces, no hay motivo para extrañarse del hecho de que a Sócrates le fuera imputado el cargo de impiedad y fuera juzgado por ofensas políticas. Por el contrario, hubiera sido magnífico que los acusadores se hubieran abstenido de sacar provecho de las acusaciones que podrían estar basadas en las críticas de Sócrates a la democracia en sus discusiones.

Respecto al segundo argumento: ¿es verosímil que los acusadores en el 399 culparan a Sócrates de ofensas políticas que no fueran mencionadas en las apologías de Platón y Jenofonte, sino solo en la Memorabilia de este último? Creo que sí, por las siguientes razones: es notable que en ambas apologías Sócrates haya estado en contra de Meleto y no haya tenido nada qué decir respecto a Licón y Ánito ${ }^{21}$. En la Apología de Platón, Sócrates dice que Ánito habla en defensa de los líderes políticos y los artesanos mientras que Licón representa a los oradores, y Meleto, a los poetas (23e). Infiero que si alguno de los acusadores le imputó cargos políticos a Sócrates tuvo que haber sido Ánito. Luego, en su Apología,

20 En 338, por ejemplo, después de la derrota en Queronea, Demóstenes fue puesto en juicios a través de toda clase de procesamientos públicos y casi tuvo que defenderse diariamente en la corte, cada vez en un nuevo juicio (Dem.18.249).

21 Ánito es mencionado en Platón, Apol., 18b, 25b, 28a, 30b, 30c, 31a, 34b, 36a. En 23 ese nos cuenta que él representa a los artesanos y a los líderes políticos. Adicionalmente, en $29 \mathrm{c}$ es citado por haber declarado que, desde que Sócrates ha sido puesto en juicio, los jurados deben dar la sentencia de muerte, de otro modo habría sido mejor evitar el juicio completamente. Se hace referencia a Licón únicamente en 23e (como un representante de los rethores) y en 36 . 
Jenofonte nos dice que Sócrates tenía synegoroi, defensores que se dirigen a los jurados después de que Sócrates haya terminado su discurso ${ }^{22}$. Esta pieza preciosa de información ha sido olvidada y silenciada ${ }^{23}$ por aquellos que han discutido el juicio de Sócrates; sin embargo, no veo razón para cuestionar la veracidad de lo dicho por Jenofonte. Uno podría objetar que Sócrates no les habría permitido a sus amigos aparecer en el juicio como sus synegoroi, ya que esto no coincidía con su postura frente al juicio. Una objeción en este sentido puede ser contrariada si nos remitimos a los arreglos de la sentencia. Primero, Sócrates propuso una multa ridículamente pequeña que, al aceptar la oferta de sus amigos, aumentó a medio talento (suma considerable y realista). De manera similar, Sócrates pudo haber rechazado la primera oferta de sus amigos de aparecer como sus synegorioi, (no sabemos) pero al final cambia de parecer. Lo que sí sabemos es que hubo synegoroi presentándose a favor de Sócrates, lo cual nos ofrece una explicación sobre el silencio en las apologías de Platón y Jenofonte frente a los cargos políticos a Sócrates. En su discurso, Sócrates se refirió a las acusaciones hechas por Meleto y le dejó a sus synegoroi la refutación de los cargos presentados por Ánito y Licón.

Yo concluyo que, de hecho, Ánito acusó a Sócrates de haber criticado a las instituciones democráticas y que estas acusaciones no entraron en conflicto con la amnistía del 403. Dado que Polícrates parece haber incluido las acusaciones políticas contra Sócrates en su tratado, terminamos con la siguiente relación entre las fuentes:

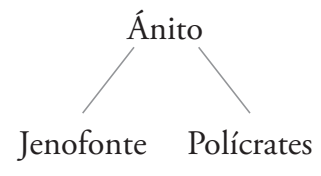

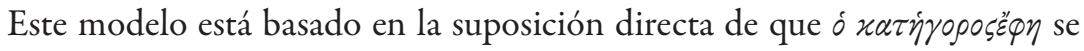
refiere al acusador en 399 y no a un ataque póstumo y literario a Sócrates. Pero, incluso, por el bien de la discusión, adoptamos la visión aceptada y asumimos que en su Memorabilia, Jenofonte se muestra en contra de Polícrates, el resultado es más o menos el mismo: la presunción de que las acusaciones discutidas por

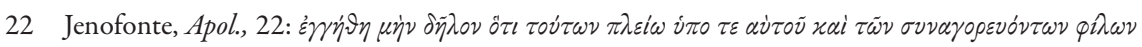

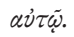

23 Ver: Brickhouse \& Smith, 1989, p. 76, referido en la nota 50 a la versión danesa de su estudio. 
Polícrates en su tratado no fueron inventadas por él, sino que se basaron en efecto en lo dicho en el 399. En este caso, la relación entre las fuentes es la siguiente:

$$
\begin{gathered}
\text { Ánito } \\
\text { Polícrates } \\
\text { Jenofonte }
\end{gathered}
$$

\section{Una reconstrucción del juicio}

DeSPUÉS DE EXAMINAR LAS FUentes me dispongo a reconstruir el juicio.

En el arconte de Laques (400/399) ${ }^{24}$, más específicamente en el invierno del $399^{25}$, Sócrates fue acusado por Meleto, el hijo de Meleto de Piteas ${ }^{26}$; Litón, de procedencia desconocida ${ }^{27}$, y Ánito, hijo de Anthemion de Euonymon ${ }^{28}$. Fue llevado a juicio acusado de la ofensa graphe asebeias, una acción pública por impiedad, y enviado al rey Arconte por Meleto ${ }^{29}$. Por consiguiente, Meleto sería el responsable de una multa de 1000 dracmas si obtenía menos de un quinto de los votos de los jurados ${ }^{30}$. El texto de la acusación ha sobrevivido y dice lo siguiente: "Bajo juramento, Meleto hijo de Meleto de Piteas, ha acusado y llevado a juicio a Sócrates, hijo de Sofronisco de Alopecia, por las siguientes ofensas: Sócrates es culpable de no reconocer a las divinidades reconocidas por la ciudad y por dar conocer nuevas divinidades. Además, es culpable de corromper a la juventud. Condena sugerida: pena capital" ${ }^{\prime 1}$. La acusación fue oída por un panel de quinientos

24 Ver: Diógenes Laercio, 2.44 (= Dem. of Phal. FGrH 228 fragmento10); Marmor Parium (FGrH 239) A66.

25 El caso fue oído el día después de la partida de $\theta \dot{c} \omega$ por para Delos (Platón, Fedón, 58a), i.e. en el mes de Antesterion (Deubner,1932, pp. 203-204).

26 Ver: Platón, Eutifrón, 2b; Diógenes Laercio, 2.40; Kirchner, PA 9830; MacDowell, 1962, pp. 208-210.

$27 \mathrm{Al}$ respecto, véase el apéndice 3 al final del texto.

28 Para el patronímico y demótico, ver: Davies, 1971, pp. 40-41

29 Platón, Euti.,2a-c, 5c;Teet., $210 \mathrm{~d}$.

30 Platón, Apol., 36a. Ver, además: Hansen, 1975, pp. 29-30.

31 La acusación es citada en: Diógenes Laercio, 2.40, y parafraseada en: Platón, Apol., 24b; Euti, 3b; Jenofonte, Mem.1.1.1, 1.2.64; Apol. 10. El juramento hecho por Meleto es mencionado en: Platón, Apol., 27c. 
un (501) jurados a la cabeza del Rey Arconte. Al ser Meleto el acusador principal, pronunció el primer discurso imputándole a Sócrates el cargo de corromper a los jóvenes al discutir y propagar las visiones críticas de los filósofos naturalistas frente a los dioses (Platón, Apol., 26d; Jenofonte, Mem., 1.1.12-15) y haber actuado como un oráculo no autorizado invocando a su daimonion (Platón, Apol., 27c; Jenofonte, Apol.10, 12-13; Mem.1.1. 2-9). Licón y Ánito aparecen como synegoroi de Meleto (Platón, Apol., 36a). No conocemos lo dicho por Licón, pero Ánito tuvo que haber acusado a Sócrates de corromper a los jóvenes con su crítica subversiva de las instituciones democráticas ${ }^{32}$ : Sócrates ya habría influenciado a Critias y a Alcibiades, dos de los más peligrosos enemigos del pueblo (Jenofonte, Mem., 1.2. 12; Isócates, 11.5). A causa de la amnistía no podían pedirle cuentas de sus acciones antes del 403. Sin embargo, como sostenía la misma posición y no cesaba de divulgarla, existía el riesgo de que sus seguidores se unieran a un tercer intento de sabotear la democracia. Los acusadores llamaron a diferentes testigos (Jenofonte, Apol., 24). Algunos se habían sentido ridiculizados al discutir con Sócrates, mientras otros simplemente habían asistido a dichas discusiones.

Sócrates, por su parte, dio la impresión en su defensa de estar actuando improvisadamente (Platón, Apol., 17c-18a; Jenofonte, Apol., 3ff) y se limitó a refutar a los cargos imputados por Meleto. Negó haber tenido un interés particular en la filosofía natural (Platón, Apol., 26d; Jenofonte, Mem., 1.1.11-15) e invocó a su daimonion como evidencia de no ser ateo (Platón, Apol., 27a-28a; Jenofonte, Apol., 10-13; Mem., 1.1.4-5). Además de esto, el propósito de sus discusiones con los jóvenes, principalmente ricos (Platón, Apol., 23c), era hacerlos mejores, no corromperlos. La respuesta del oráculo de Délfos, de que ningún hombre es más sabio que Sócrates ${ }^{33}$, fue uno de los puntos principales traídos por Sócrates en su defensa (Platón, Apol., 20e-23b; Jenofonte, Apol., 14-15). Dado que Querefonte había muerto, Sócrates hizo testificar lo anterior por el hermano (Platón, Apol., 21a). Los cargos presentados por Meleto fueron de nuevo refutados en un

32 Ánito habla en favor de los líderes políticos (Platón, Apol., 23e: politikos es raramente usado por los oradores en el sentido de líder político. Véase: Aeschin, 2.184). Se enfoca en el cargo de Sócrates por haber corrompido a los jóvenes. (Platón, Apol., 29c) y él es probablemente el $\varkappa \alpha \tau \eta \dot{\gamma} \gamma o \rho \circ \varsigma$ que trajo los cargos políticos mencionados por Jenofonte en Mem.1.2.9, 12.

33 Ver apéndice 4. 
interrogatorio en el cual Meleto contradijo sus propias afirmaciones (Platón, Apol., 24c-27d, 23b; Jenofonte, Apol., 19-21). Los cargos que imputaron Licón y Ánito fueron dejados de lado, Sócrates solo se refirió a las acusaciones políticas de manera indirecta, al recordarles a los jueces su comportamiento constitucional durante el juicio de los generales (Platón, Apol., 32b-d; Jenofonte, Mem., 1.1.18) y su oposición a los Treinta Tiranos rehusándose a ayudar en el arresto de León (Platón, Apol., 32d).

Después del discurso del propio Sócrates, algunos de sus amigos se presentaron como sus synegoroi (Jenofonte, Apol., 22). Ellos probablemente se refirieron a las acusaciones hechas por Ánito y Licón sobre la propagación de las visiones no democráticas de Sócrates. Después de la audiencia, los jueces votaron. Se nos ha dicho que Sócrates hubiera sido absuelto si 30 jurados hubieran votado diferente, lo que significa que una mayoría de 59 o 60 votó en su contra. Si el número de 30 votos es correcto, entonces podríamos inferir que los votos tuvieron una distribución de 280/221 o 280/220 $0^{34}$ en caso que alguno de los jueces se abstuviera de votar.

La condena estipulaba la pena capital (Platón, Apol., 35e-18a; Jenofonte, Apol.,24-26) y Meleto tuvo que haberle sugerido a los jueces que Sócrates debía ser sentenciado a muerte y ejecutado. Al principio, Sócrates se rehusó a proponer una alternativa realista a la pena capital. Incluso, pudo sugerir que permanecer en el Pritaneo el resto de su vida era una pena apropiada. Después, propuso una multa que él podía pagar. i.e., media mina. Eventualmente, cuando algunos de sus amigos prometieron pagar por él, Sócrates propuso pagar 30 minas, es decir una multa de medio talento (Platón, Apol., 35e-18a; Jenofonte, Apol., 24-16). Cuando llegó la hora de la votación para definir la pena, la propuesta de Meleto pasó con una mayoría aún más grande que la que dictaminó el veredicto de culpabilidad ${ }^{35}$.

Con la segunda votación el juicio se había acabado pero, por iniciativa propia, Sócrates dio un tercer discurso a los jurados (por lo menos a aquellos

34 Ver: Erasmus, 1964, pp. 40-42. IG II2 1641B registrando un voto hecho por 499 jurados.

35 Diógenes Laercionos dice (2.42) que cuando el segundo voto fue hecho la mayoría fue incrementada por 80 votos. Como la información de Diógenes del primer voto es equivocada (una mayoría de 281 votos) no podemos confiar tampoco en la segunda cifra. No obstante, podría estar en lo correcto acerca de que los acusadores ganaron una gran mayoría cuando los jurados votaron en la sentencia. 
interesados en escuchar) en el que reflexionó sobre el significado de la muerte, en general, y en particular, sobre la sentencia de muerte que acababa de recibir (Platón, Apol., 38c-42a; Jenofonte, Apol., 24-26).

\section{Las acusaciones políticas}

DESPUÉS DE LA RECONSTRUCCIÓN DEL JUICIO voy a examinar los dos cargos que se elevaron en contra de Sócrates, por una parte, el cargo por impiedad y, por otra, el cargo político. Me propondré buscar ejemplos y fuentes que arrojen una luz sobre el punto de vista ateniense acerca de la impiedad en relación con la libertad de conciencia, así como la posición acerca de las creencias antidemocráticas concernientes a la libertad de expresión.

La acusación contra Sócrates no fue la única de su tipo que fue escuchada en Atenas en esos años. Unos meses antes, los atenienses habían exonerado a Andócides de un cargo por impiedad (Andócides, 1 ) $^{36}$ y, en ese mismo año, Nicómaco fue acusado por asebeia en conexión con su codificación de las leyes de Atenas $\left(\right.$ Lisias, 30) ${ }^{37}$. Parece que en el 400-399 hubo abundantes acusaciones relacionadas con ofensas religiosas ${ }^{38}$, y no hay razón para asumir que el juicio de Sócrates fue provocado por una actividad especial en la que estuviera involucrado. Sócrates fue hallado culpable por lo que creía sobre los dioses y, probablemente, también por su posición crítica frente a las instituciones democráticas atenienses. Hay un fragmento muy interesante de Hipérides que suele ser pasado por alto por aquellos que escriben sobre el juicio de Sócrates. En su discurso contra Autocles, Hipérides (fragmento 59) recuerda a los atenienses que sus padres habían castigado a Sócrates por sus palabras, epilogois ${ }^{39}$ i.e. no a causa de lo que hubiera hecho. Este fragmento y el veredicto por sí mismo muestran que los atenienses no hubieran garantizado a Sócrates lo que hoy se denomina la libertad de

36 Para una descripción del juicio ver: Hansen, 1976, pp. 128-130, Cat.No.10. Para la fecha ver: MacDowll, 1962, pp. 204-205.

37 Para una descripción del juicio ver: Hansen, 1975, pp. 116-117, Cat. No. 140.

38 Para una buena referencia de estos juicios ver: Connor, 1991.

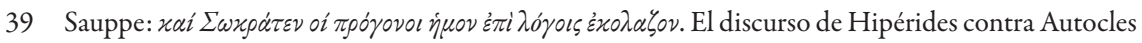
fue pronunciado en 361-360, i.e. no más de una generación después del juicio de Sócrates. 
expresión y de conciencia, bien sea porque dichas libertades no eran ideales aceptados por los demócratas atenienses, o bien, porque la democracia ateniense se parecía en este aspecto a las democracias modernas, donde la libertad de expresión y conciencia son añoradas como ideas centrales, pero los demócratas no siempre viven a la altura de sus propias ideas, ni siquiera en estados que regularmente se precian de ser democráticos.

Comenzaré con la discusión sobre la libertad de expresión que suele llamarse parresia en nuestras fuentes. Considero que es superfluo sostener aquí que la parresia ateniense era tan cercana a la libertad de expresión democrática moderna como lo podría ser cualquier otro concepto antiguo a su equivalente moderno (Raaflaub, 1985, pp. 277-283). Todas las fuentes muestran que libertad de expresión era un ideal preciado por los demócratas atenienses. Basta mencionar que los atenienses tenían un trirreme llamado parresia ( $\left.I G l l^{2} 1624.81\right)$, como se puede referir a la observación de Demóstenes (20.105-108) que expone que una diferencia básica entre la oligarquía espartana y la democracia ateniense es que en Atenas se es libre de alabar la constitución espartana y su forma de vida, mientras que en Esparta está prohibido alabar cualquier otra constitución que no sea la espartana.

Sin embargo, la alabanza a la constitución espartana pudo haber sido lo que ofendió a los atenienses y lo que los acusadores sostenían contra Sócrates durante el juicio. Como se argumentó antes, una de las acusaciones políticas que se hizo contra Sócrates fue que él prefería que la elección de magistrados fuera hecha por muchos y dijo que el sorteo era ridículo (Jenofonte, Mem., 1.2. 9; Aristóteles, Ret., 1393b3-8). Ahora, Isócrates (12.153-154, 7.21ff), por ejemplo, enfatizó que una diferencia básica entre la constitución ateniense y la espartana es que los magistrados son elegidos en Esparta y seleccionados por sorteo en Atenas. Adicionalmente, en el Gorgias (515e) de Platón, cuando Sócrates critica la democracia ateniense, Calicles replica que la crítica de Sócrates es un eco de lo que dicen aquellos con oídos de coliflor. "Tener oídos de coliflor" era un epíteto bien conocido para referirse a aquellos que admiraban e imitaban la forma de vida espartana $a^{40}$. Las fuentes forman una síntesis cuando agregamos que

$40 \mathrm{Al}$ respecto, ver también: Jenofonte, Apol., 15, donde Sócrates se compara así mismo con Licurgo, el legislador espartano. De manera similar en: Platón, Crit., 52e, donde Sócrates se refiere a su 
Polícrates, aparte de su Kategoria Sokrate, era autor de una sátira de los espartanos titulada Kategoria Lakedaimonion.

Resumo. La libertad de expresión era probablemente el ideal democrático ateniense más preciado; en Demóstenes se ejemplificó como el derecho a alabar la constitución espartana a costa de la ateniense. Sabemos que muchos ciudadanos y metecos se beneficiaron de esta libertad de expresión y no fueron nunca llevados a juicio. Platón, Isócrates y Aristóteles son los tres personajes más prominentes, pero hay muchos otros. El juicio de Sócrates es, en efecto, el único caso del que existe testimonio de un ateniense llevado a juicio por lo que pensaba o decía ${ }^{41}$. En todos los otros casos relacionados con comportamientos antidemocráticos se acusa por conspiración, traición y corrupción. Pero, hay una diferencia importante entre Sócrates y los otros tres que he mencionado. Platón, Isócrates y Aristóteles eran maestros, y solo enseñaban a aquellos que frecuentaban sus escuelas. Sócrates era probablemente más prominente y más reconocido. La elección de Aristófanes para que Sócrates representara a los sofistas en Las nubes indica fuertemente que Sócrates era una figura reconocida en Atenas. Lo que era peligroso de Sócrates no eran sus puntos de vista sobre la democracia, sino la propagación de dichos puntos de vista a todos los que acudían a sus discusiones diarias en el Ágora (Platón, Apol., 18c, 19d, 33b).

La condena y ejecución de Sócrates demuestra que Atenas no siempre vivía a la altura de sus propios ideales. No obstante, el hecho de que dichos ideales no fueran tan solo palabras vacías se hace ostensible porque se presupone que el juicio de Sócrates fue único en la historia de Atenas; después de todo, Sócrates vivió 70 años en los que seguramente criticó con regularidad las instituciones democráticas. Como lo observa correctamente George Grote (1846-1856, 9.86), si

admiración hacia las leyes espartanas. Igualmente en: Ar., Av.1281-1282, donde Sócrates es relacionado de nuevo con círculos pro-Laconianos.

41 Si podemos confiar en los escolios, Ar. Ach. 67, un decreto limitando el derecho a ridiculizar en comedias fue pasado en 440-439, pero fue abolido de nuevo en 437-436. No tenemos información acerca de ningún juicio certificado por este acto. Ver: Schol. Ar., Av.1297. De nuevo, si podemos confiar en la interpretación de los escoliastas en Ar., Ach. 376-382, Kleon, porque él fue ridiculizado en los Babilonios, arrastra a Aristófanes ante el Consejo de los Quinientos y lo acusa de haber ridiculizado a los magistrados en frente de los extranjeros. Pero, Aristófanes no dice que haya sido puesto en juicio e, incluso, suponiendo que Kleon trajo alguna clase de acción pública, tendremos que inferir que Aristófanes fue absuelto. 
Sócrates fuera un ciudadano en una de las utopías de Platón, nunca hubiera llegado a la edad de 70 años ${ }^{42}$.

Si se me permite una digresión, no puedo dejar de pensar que la crítica de Sócrates a la elección por sorteo de magistrados es más bien sofística. Qué tan absurdo es, dice Sócrates, elegir un magistrado en un sorteo cuando usted no elegiría un timonel de esta manera. El sofisma reside en la premisa que sugiere que un magistrado tiene el mismo poder de dirigir el barco de la ciudad como el timonel lo tienen de dirigir su barco. Pero, los atenienses eligen sus magistrados en un sorteo precisamente para asegurarse que no sean los timoneros de la ciudad. Uno de los propósitos del sorteo era disminuir el poder de los magistrados. El sorteo no se basaba en la idea de que todos era igualmente versados, pero que todos los hombres sí lo eran suficientemente para lo que eran elegidos y que, por el uso del sorteo para las magistraturas, cesarían de ser atractivas como armas para la lucha por el poder. ${ }^{43}$ Permítanme ilustrar el punto con un diálogo ficticio, a la manera de Platón, entre Sócrates y un demócrata ateniense llamado Ánito.

An. ¿No es cierto, Sócrates, que en una ciudad no hay pocas sino muchas cosas para hacer?

Só. Ciertamente, así es.

An. Por ejemplo, es necesario que una ciudad ahora construya un muro, que asegure que suficientes granos estarán disponibles para que los ciudadanos puedan adquirirlos y muchas otras cosas.

Só. En efecto.

An. También estaríamos de acuerdo, o no, que ¿entre más grande la ciudad más numerosas son las tareas que debe asumir?

Só. Si, estoy de acuerdo.

An. Ahora, isolo hace un tiempo decíamos que una determinada tarea es mejor cumplida si es asignada a un hombre que tiene la experticia en el oficio que se requiere?

Só. Muy cierto.

$A n$. Y, no es posible para un hombre ser versado en diversos oficios al mismo tiempo. Así, un hombre que desea ser a la vez timonel, zapatero, herrero y actor no podrá tener tanta destreza en todas las ocupaciones como aquel que

42 La observación de Grote fue repetida por Karl Popper (1945, pp. 194-195).

43 Ver: Hansen, 1991, 235-137. 
dedica toda su vida obteniendo una comprensión profunda de solo una ocupación.

Só. Eso es correcto.

Án. Pero en ese caso, si asignamos las tareas de gobernar la ciudad a solo un hombre o a unos pocos, entonces estos solo podrán poseer el conocimiento necesario en relación con un bajo número de las cosas que tienen que ser hechas.

Só. Sí.

Án. Pero, entonces, seguramente, se sigue que entre más personas participen del gobierno de la ciudad, cada uno versado en su determinado oficio, será mejor será gobernada, y entre más grande la ciudad más cierto será esto.

Só. Sí.

An. Ahora, me puede decir Sócrates ¿qué constituciones se pueden hallar en Grecia?

Só. Ciertamente, esto no es difícil, para aquellos que se ocupan con esas preguntas dígase que hay tres tipos, a saber: monarquías, oligarquías y democracias. An. Ahora, ¿en cada una de estas constituciones quiénes son los gobernantes? Só. En la monarquía es el rey o el tirano, en la oligarquía son los magistrados que fueron elegidos, mientras que en la democracia es la asamblea.

Án. Bueno, entonces, si la ciudad es gobernada de la mejor forma posible ¿dónde encontraría uno el mayor número de expertos? ¿Con el rey, que está solo asistido por un reducido número de asistentes? ¿Con los magistrados, oligarcas que fueron, por su puesto, elegidos por su conforme a su riqueza? o ¿̇con la asamblea democrática donde es posible para todos ir y hablar?

Só. [Vacilando]: en la asamblea democrática.

Án. Entonces la democracia debe ser el tipo de constitución que mejor permite la expresión del conocimiento real y, por lo tanto, debe ser la mejor constitución.

Só. Bien, Ánito, ese parece ser el caso. Pero, no puedo evitar contemplar algunas dudas sobre este asunto. En una asamblea solo unos pocos expertos van a estar presentes cuando un asunto va a ser debatido, mientras que habrá muchos ignorantes presentes. Pero, entonces, cuando algo es sometido a voto, las manos de todos quienes son ignorantes serán muchas más que las de los expertos. Si, por otra parte, usted asigna la tarea de gobernar la ciudad a un número menor de magistrados, cada uno experto en su propio campo, usted no correría el riesgo de que los expertos fueran superados en número por aquellos que son ignorantes. 
An. Puede haber algo de verdad en eso, pero le suplico considerar lo siguiente: ¡es un hombre que es ignorante totalmente ignorante o es, como regla, lo suficientemente entendido para recibir consejos de un experto en vez de alguien que no tiene ningún conocimiento?

Só. No entiendo muy bien.

An. Bueno, Sócrates, jes usted un experto en caballos?

Só. No.

An. Ahora, si usted fuera a comprar un caballo y un zapatero le recomendara comprar un determinado caballo, pero el veterinario le recomendara otro ¿a quién de los dos escucharía?

Só. Al veterinario, por su puesto.

An. Si usted estuviera en la asamblea y en la discusión sobre el número que conformaría la caballería, tanto el zapatero como el veterinario hacen propuestas distintas ¿no votaría usted en este caso también por la propuesta hecha por el veterinario?

Só. Así lo haría.

An. En la asamblea todos los ciudadanos están presentes o, al menos, la mayor cantidad posible.

Só. Esto es cierto.

An. Y toda vez que un asunto determinado se deba debatir entonces habrá expertos presentes.

Só. Esto es lo más probable.

An. Pero, como nadie comete errores voluntariamente, y como todos están dispuestos a obtener consejo de un experto en lo que es correcto, entonces quien es ignorante seguirá el consejo de los expertos en vez de aquel que no sabe nada.

Só. Sí.

An. Entonces, una asamblea democrática debe ser un cuerpo gobernante que contenga la mayor suma de conocimiento y, como todo, el verdadero gobierno está basado en el conocimiento, entonces se sigue que la democracia es la mejor constitución.

Só. Debo concederte eso. ${ }^{44}$

44 La idea básica detrás de este corto diálogo es mencionado y debatido por Aristóteles en Politica, Libro 3 capítulo 11, 12811 a 39ff. Como en los genuinos diálogos socráticos hay imperfecciones en la argumentación, pero -como en Platón- los dejaré para que el lector los encuentre. 
Paso ahora al cargo que oficialmente se levantó contra Sócrates: el cargo de impiedad. En este caso también es apropiado preguntar: ¿es el juicio de Sócrates único en la administración de justicia ateniense o casos similares pueden ser encontrados? Responder esto es difícil porque nuestra fuente ha sido confundida con el mito que creció alrededor de Sócrates. El graphe asebeias en contra de Sócrates ha hecho casi imposible diferenciar las causas legales de las anecdóticas en las fuentes más tardías. El general más admirado en el mundo antiguo fue Alejandro Magno y tenía el hábito de inclinar ligeramente su cabeza sobre el hombro por lo que innumerables generales, después de él, caminaban con su cabeza en una inclinación. De nuevo, el admirado filósofo Sócrates fue acusado de impiedad. Después de Sócrates era digno de reconocimiento ser acusado por impiedad y los biógrafos helenistas estaban ansiosos de otorga el honor a pocos de los contemporáneos y sucesores de Sócrates: Anaxágoras, Protágoras, Pródico, Estilpón, Theódoros, Aristóteles y Teofrasto (Derenne, 1930; Dover, 1976).

Anaxágoras pudo haber sido llevado a juicio, como se ve en Derenne (1930, pp. 13-41) y Stadter (1989, pp. 298-299), pero la evidencia de todos los demás juicios públicos contra filósofos por impiedad es anecdótica y poco fiable porque no cuenta con información adicional. Incluso, el juicio contra Anaxágoras puede no haber sucedido (Dover, 1976, p. 29ff). Si nos fiamos de nuestras fuentes, para poder tener una ley que garantizara un caso de esta naturaleza, un tal Diopites tenía que proponer y realizar un decreto donde las acusaciones se elevaran contra ateos y astrónomos, probablemente endíadis para ateos astrónomos ${ }^{45}$. En todo caso, la necesidad urgente de un decreto para poder enjuiciar a Anaxágoras indica que los atenienses usualmente no interferían con lo que las personas pensaban sobre los dioses, siempre y cuando no profanaran los misterios, mutilaran las Hermas o cometieran actos de impiedad.

Todavía se cree, comúnmente, que el juicio de Sócrates se autorizó por un decreto de Diopites (Connor, 19991, p. 50), pero no podemos olvidar que el código de leyes atenienses se revisó en 403-402 y que las leyes que no estaban incluidas en el código revisado no eran válidas (MacDowell, 1962, pp. 125-126,202, seguido por Hansen, 1990, pp. 66-68). El decreto de Diopites en contra de los astrónomos ateos, si era genuino, ciertamente fue diseñado específicamente para

45 Ver: Plut., Per., 32.2-5; Mor. 169e; Diod., 12.39.2; Diógenes Laercio, 2.12. 
acomodarse al juicio de Anaxágoras. Consecuentemente, es improbable que sobreviviera la codificación en 403-402 y que fuera incluido en el código revisado.

Aparte del juicio contra Anaxágoras, solo hay un testimonio de una graphe asebeias elevada contra un ateo, el juicio de Diagoras, llamado hoatheos ${ }^{46}$. Pero, incluso Diagoras, no había sido acusado de ser un ateo, sino de haber revelado misterios a una persona sin iniciación ${ }^{47}$. Entonces, recordemos que Meleto, cuando estaba contra interrogando a Sócrates, casi que automáticamente se refiere a Anaxágoras. La razón de esto puede ser que el juicio de Anaxágoras (que sí tuvo lugar) era el único precedente de una personas que fue acusada de no creer en dioses tradicionales.

La segunda y tercera parte de la acusación es, en efecto, más seria que la primera. "Sócrates delinque corrompiendo a los jóvenes y no creyendo en los dioses en los que la ciudad cree, sino en otras divinidades nuevas" (Platón, Apol., 24b). Los atenienses garantizaban a los ciudadanos una cierta libertad de conciencia privadamente pero no toleraban que una persona, sin una autorización adecuada, introdujera nuevos cultos e intentara convertir a generaciones más jóvenes. Se encuentra ampliamente documentado la forma como los atenienses trataban ese comportamiento.

Friné, la amante de Hipérides, fue llevada a juicio a través de un graphe asebeias por haber introducido una nueva divinidad y por haberse rodeado de jóvenes prosélitos. Ella fue encontrada inocente en el juicio (Hipérides, fragmentos $102-$ 110). Menekles elevó una graphe asebeias contra Ninos, la sacerdotisa. Ella fue acusada de haber administrado una poción, probablemente un afrodisíaco, a sus jóvenes devotos. Menekles obtuvo una condena contra Ninos y esta fue sentenciada a muerte ${ }^{48}$. Theoris de Lemnos fue acusada de la misma ofensa que Ninos, igualmente, fue enjuiciada y sentenciada a muerte en conjunto con toda su familia ${ }^{49}$.

\footnotetext{
46 Ver: Ar., Av.1071-1078; Lisias, 6.17-18.

47 Ver: Krateros FgrHist., 342 fr.16 = schol. Ar., Av. 1073 y otras fuentes fueron recogidas por Jacoby (1959).

48 Ver: Demóstenes, 39.2, 40.9; Demóstenes, 19.281 con escolios. Jos., Ap., 2.37.267.

49 Ver: Demóstenes, 25.79; Philoch. FgrHist, 328, fragmento 60.
} 
Quisiera sostener que es el mismo Sócrates el que conecta el cargo por impiedad con el cargo por corrupción de los jóvenes. Tanto en la Apología (29c) de Platón y en el Eutifrón (3c) Sócrates dice que a los atenienses no les importa lo que él piense, pero que lo consideran un profesor y que no van a tolerar. Acá hay una clara diferencia entre la noción ateniense y el moderno concepto de libertad de conciencia. Los atenienses no hubieran permitido comunidades religiosas privadas y no autorizadas. Desde el punto de vista jurídico, el cargo más serio que podía ser levantado contra Sócrates era, sin lugar a dudas, que él corrompía los jóvenes que lo rodeaban mientras actuaba como un oráculo privado dando consejos de su daimonion. Sócrates no fue juzgado por ser ateo pero sí por ser un misionero.

Recapitulemos. Sócrates fue sentenciado por no compartir el punto de vista ordinario de los atenienses sobre los dioses y, probablemente, por haber criticado las instituciones democráticas. Como se dijo antes, el juicio de una persona que tenía sus propios puntos de vista sobre los dioses era raro, y el de una persona que criticaba las instituciones democráticas, único. La presuposición es que Sócrates no fue llevado a juicio por tener dichas opiniones, sino por haberlas propagado entre sus seguidores día tras día, año tras año. En ese caso, la pregunta pertinente tiene que ser: ¿quiénes eran las personas que se agrupaban alrededor de Sócrates y escuchaban sus discusiones en el Ágora? En la Apología (23c) de Platón, Sócrates le dice a los jueces que la mayoría de sus seguidores eran jóvenes y ricos porque eran quienes tenían el tiempo disponible para frecuentar el Ágora durante la semana. Es preocupante que la crítica de Sócrates a las instituciones democráticas atenienses fuera ventilada entre los ricos y los jóvenes. En general, un hombre rico preferirá la oligarquía a la democracia (Aristóteles, Pol., 1279b 39) y los jóvenes eran conocidos, célebres por su propensión a revolucionar el establecimiento. Recordemos que la palabra griega para revolución es neoterismos ${ }^{50}$. Entonces miremos más de cerca al círculo alrededor de Sócrates.

En los diálogos de Platón conocimos el nombre de unas 60 personas. Me he concentrado en aquellas que contribuyen a la discusión. El elenco podría ser extendido incluyendo los nombres de aquellos que no hablaron y aquellos que fueron mencionados pero no estuvieron presentes. Incluso, la lista podría ser mucho

50 Ver: Thuc, 6.12-13, 38-40; Eur., Suppl., 232-237; Platón, Lg., 798b-c. 
más larga si incluimos las personas que conocimos en los diálogos socráticos de Jenofonte.

Así, el grupo que estudio acá es el elenco que se conoce por los diálogos de Platón. Se trata de sesenta personas de las cuales 30 no se conocen en el sentido de que Platón no nos informa ni quiénes son, ni qué son y tampoco son conocidos a través de otras fuentes. De nuevo, al menos la mitad de las restantes treinta personas o bien son sofistas viajeros (como Protágoras, Gorgias, Hipias y Pródico) o extranjeros quedándose en Atenas (como Menón) o poetas (como Aristófanes y Agatón). De esta forma, nos quedan las quince personas que conocemos solo como participantes en las discusiones conducidas por Sócrates, pero que también eran participantes en la política ateniense. De esos solo cinco eran demócratas leales y los otros diez eran ovejas negras y personas con poca reputación que los atenienses sentenciaron a muerte usualmente in absentia.

Comencemos con una presentación de los cinco demócratas. Primero, está Querefonte que preguntó por el oráculo délfico si había alguien más sabio que Sócrates. Él estaba entre los demócratas que tuvieron que exiliarse en el 404 durante el gobierno de los Treinta Tiranos (Kirchner, PA, p. 15203; Platón, Apol., 21a). Después, vienen los generales Nicias (Kirchner, PA, p. 10808) y Laques (Kirchner, PA, p. 9019) a quienes conocimos en Laches y, adicionalmente, Calicles, del que tenemos noticia porque Sócrates conoció a Protágoras en su casa. Calias sirvió como strategos en 391-390 y fue uno de los enviados por Atenas a Esparta en el 371 (Kirchner, PA, p. 7826). Finalmente, encontramos a Ánito quien en Menón (90b-95a) es persuadido a unirse a la discusión como efectivamente lo hace hasta que se retira por los fuertes cuestionamientos que le hacen. Él no puede ser llamado propiamente un seguidor de Sócrates, en cuyo caso, dentro del círculo que rodea a Sócrates se cuentan no cinco, sino cuatro buenos demócratas.

Es fácil encontrar traidores e ingratos dentro del círculo de amigos y seguidores de Sócrates: en Parménides se nos presenta a Pitodoro, quien sirvió de stratego en el 425-424, pero fue destituido por el cargo de traición y sentenciado a muerte in absentia (Kirchner, PA, p. 12399; Hansen, 1975, pp. 73-74, Cat. No. 8). En el 415, no menos de 5 amigos de Sócrates fueron condenados por haber profanado los misterios y/o mutilado a Hermes. Fueron: Fedro, conocido por el diálogo que lleva su nombre; el doctor Erixímaco del Simposio y su padre Acúmeno, referido 
en el Fedro; Axioco, conocido por el diálogo que lleva su nombre, y el último, y no menos importante, Alcibiades, quien además de profanar los misterios ofendió a los atenienses en otras ocasiones ${ }^{51}$. Si nos adelantamos, conoceremos a Clitofón en la República y en el diálogo Clitofón (Kirchner, PA, p. 8546). Él fue identificado con considerable seguridad como el líder político que propuso y llevó a cabo la cláusula del decreto que instauró a la oligarquía de los Cuatrocientos en la primavera del $411^{52}$. En Laques aparece Melesias, hijo de Tucides, quien era uno de los Cuatrocientos y fue indudablemente exiliado después de la derrota de los oligarcas en el otoño del 411 (Kirchner, PA, p. 9813). Al regresar a la oligarquía del 404-403 nos topamos con dos de los amigos más notorios de Sócrates: Critio, el líder del ala extremista de los Treinta Tiranos (Kirchner, PA, p. 8792), y su pariente, Cármides, quien era el líder del comité ejecutivo instaurado por los Treinta Tiranos en Pireo (Kirchner, PA, p. 15512). Ambos murieron en la batalla de Muniquia, por lo que evitaron ser considerados responsables cuando la democracia fue restaurada en el 403.

No se puede negar que el juicio de Sócrates se hace más notable y visible por la galería de personajes que participan en los diálogos de Platón. Puede que los atenienses hayan sabido que Sócrates no tenía intención de derrocar la democracia, pero Sócrates seguía divulgando visiones críticas frente a las instituciones democráticas, frente a blasfemos, oligarcas y traidores. Todos conocemos lo que se dice: "Dime con quién andas y te diré quién eres". Como muchos otros dichos, este es de origen griego y puede ser encontrado en el siguiente fragmento de la obra perdida de Eurípides llamada Fénix.

Que ya de muchos hechos llegó a ser juez, en la manera en que ahora ustedes juzgan, y las sentencias dice que se determinan no desde los testimonios, sino de los comportamientos y de las relaciones; para ello se observa cómo vive la vida de cada día el imputado, y de qué modo atiende a su propia casa, porque de un modo similar administrará las cosas de la ciudad, y con quién disfruta tener intimidad. (Esquines, Contra Timarco)

51 Fedro (Kirchner, PA, pp. 13950, 13960); Erixímaco (Kirchner, PA, p. 5187); Acumenos (Kirchner, PA, p. 477, 478); Axíoco (Kirchner, PA, p. 1330); Alcibíades (Kirchner, PA, p. 600). Además, ver para la profanación de los misterios: Hansen, 1975, pp. 74-82, Cat. Nos. 11, 12, 13-42; para la mutilación de Hermes, los Nos. 43-60.

52 Ver: Aristóteles, Constitución de los atenienses, 29.3. 
Es un hecho que este fragmento de Eurípides es conocido por el discurso de Esquines contra Timarco (Esquines, 1.152). Después de un recuento detallado de la vida lujuriosa de Timarco, Esquines se refiere a los amigos y seguidores de Timarco como una razón más para probar su culpabilidad. Es en este contexto que cita el pasaje de Eurípides. Sabemos que aquellos que acusaron a Sócrates tienen que haber seguido la misma línea de argumentación, ya que señalaron que Sócrates había instruido a Alcibiades y a Crítio. Es Jenofonte quien más se esfuerza en disipar cualquier sospecha levantada contra Sócrates en este sentido. Afirma que Sócrates es un demócrata leal y hace todos los sacrificios para los dioses como todo el mundo. Sin embargo, incluso si tuviera razón — que seguro la tenía ${ }^{53}$ - los seguidores de Sócrates lanzaban una sombra oscura sobre su maestro: las críticas de Sócrates les daban a los oligarcas los argumentos que querían. Y bien podía haber hecho sus sacrificios en público, pero así también lo hacían sus amigos, que profanaban los misterios en secreto. ¿Quién podía saber lo que hacía Sócrates en la noche en compañía de sus ricos y jóvenes amigos? La profanación de los misterios y las dos revoluciones oligárquicas se llevaron a cabo antes de la amnistía del 403, pero Sócrates sostenía aún las mismas posturas, por lo que atenienses albergaban una vaga sospecha de que podían intentar derrocar la democracia por tercera vez.

Quizás la mejor y menos parcial referencia del juicio de Sócrates es la cita lacónica y breve referencia de Esquines en su discurso contra Timarco: "Tras que ustedes, oh atenienses, le dieron la muerte al sofista Sócrates porque se vio que había instruido a Critias, uno de los Treinta Tiranos que destruyó la democracia" ${ }^{\text {‘́ }}$ (Esquines, 1.173).

Sócrates podría haber evitado el juicio si hubiera sido más cauteloso y hubiera incurrido en un castigo menos severo, es decir, si hubiera sido más modesto. La administración de la justicia ateniense dependía de un tribunal acusador privado.

53 El hecho de que Sócrates fuera simultáneamente un crítico de la democracia y un fiel demócrata se puede inferir del hecho de que Lisias, en respuesta al panfleto de Polícrates (Escolio de Aristides, 3.480), escribiera una apología de Sócrates. Como argumentaron convincentemente Platis (1980) y Vlastos (1983, p. 206), es improbable que Lisias hubiera defendido a Sócrates en un panfleto si fuese un oligarca y cayera sobre él alguna sospecha de deslealtad frente a la restablecida democracia.

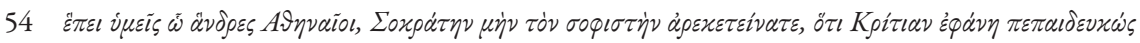

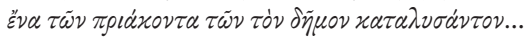


Si uno tenía un enemigo corría el permanente riesgo de ser llevado a la corte por él. Entonces, ¿qué fue lo que dijo Sócrates en el Ágora frente a los jurados cuando había sido provocado? El oráculo de Delfos ha resuelto que soy el hombre más sabio de $\operatorname{todos}^{55}$. He puesto esta respuesta del oráculo a prueba y la considero veraz. ¿Qué castigo es apropiado para este comportamiento? Ser sostenido en el Pritaneo a expensas públicas para el resto de mi vida. La humildad de un filósofo no suele distinguirse de su arrogancia ${ }^{56}$. El comportamiento de Sócrates irritó a Ánito de tal manera que se unió a los acusadores, y después irritó tanto a los jurados, que lo sentenciaron a muerte. Sócrates se tomó la condena con cierta audacia y no hizo nada para evadir las consecuencias de ser relacionado con ciudadanos de mala fama y extranjeros sospechosos. ¿Fue la condena de Sócrates un asesinato judicial o inclusive un error de la ley? No había ninguna ley que prohibiera a cualquier ateniense expresar su opinión o criticar las instituciones democráticas. Por el contrario, los atenienses se enorgullecían de su libertad de expresión y la extendían a los metecos y esclavos (Demóstenes, 9.3; Pseudo-Xenophon, Athēnaiōn politeia, 1.12). De manera similar, tampoco había una ley que prohibiera las asociaciones religiosas privadas, mientras estuvieran autorizadas por un decreto del pueblo. Entonces, es posible que no hubiera ninguna ley que justificara la condena impuesta a Sócrates. Sin embargo, acorde con en el juramento heliástico, los jurados debían actuar con la conciencia ante la ausencia de la ley (Demóstenes, $20.118 ; 39.40)^{57}$. Es probable que los jurados hayan usado este pasaje del juramento heliástico por lo menos en aquello relacionado a las acusaciones políticas. Nuestras fuentes son insuficientes para determinar si la condena impuesta a Sócrates fue imperdonable, comprensible o justificada, dado que el caso en la versión de los acusadores no puede reconstruirse con certeza. Tampoco tenemos evidencia para refutar el argumento de que al votar por la condena de Sócrates los jueces actuaron de manera honorable creyendo proteger las instituciones democráticas

55 Ver el apéndice 4 al final del texto.

56 En la Apología (1-2) Jenofonte argumenta que el comportamiento de Sócrates ( $\mu \varepsilon \gamma \alpha \lambda \eta \gamma o \rho i ́ a)$ fue comentado por todos aquellos que han escrito sobre el juicio y que fue la razón por la que los jueces lo sentenciaron a muerte.

57 Ver, también: Hansen, 1991, p.182. 
atenienses. Por lo mismo, esta investigación sobre el juicio de Sócrates debe terminar en la ignorancia Socrática con un interrogante ${ }^{58}$.

Apéndice 1

Tradicionalmente, la Apología está situada dentro de los primeros diálogos de Platón, ubicada en el año 390 (Ross, 1953, p. 2), Brandwood (1990) no aporta nada nuevo sobre la fecha de la Apología. Erbse (1975), sin embargo, argumenta que la Apología es un texto con una fecha posterior a lo que usualmente se cree. En su Apología, Jenofonte se refiere a la muerte de Ánito y si el acusador de Sócrates se puede identificar con el sitophylax mencionado por Lisias (22.8), de ello se sigue que Jenofonte no compuso su versión de la defensa de Sócrates sino hasta después del año 386. La identificación es aceptada por Platis (1980) y Vlastos (1983, p.202). No obstante, hoy día casi todos los estudiosos de la prosopografía ateniense niegan tal identificación (Develin, 1988, p. 441, Nos. 263, 265). Por lo tanto, nada nos impide ubicar la obra de Jenofonte de forma previa a la de Platón. Además, en su prefacio Jenofonte sostiene que ninguno de los recuentos existentes acerca del juicio de Sócrates menciona la postura de Sócrates según la cual, para él, la muerte puede ser preferible a la vida. Sin embargo, ese es uno de los puntos de vista que Sócrates sostiene en su tercera intervención, tal como es reportado por Platón (Apol., 38c, 41d). Por consiguiente, aunque ya hubiera Platón compuesto o no su Apología, Jenofonte escribió su tratado sin conocer el de Platón. No debemos olvidar que Jenofonte y Platón vivieron antes que Gutenberg, y que los diálogos de Platón no eran aún reconocidos mundialmente como "literatura universal". Para una detallada y convincente presentación según la cual Jenofonte escribió su Apología sin conocer acerca de la obra Platón, puede consultarse la obra de Von Arnim (1923).

58 Por las valiosas sugerencias durante y después de la discusión de este ensayo me gustaría agradecer principalmente a Walter Burkert, Robert Connor, Douglas MacDowell y Jan Pecirka. Más aún, me gustaría agradecer a Theodore Buttrey por leer y comentar el borrador, y a Lene Rubinstein por la brillante traducción al inglés que hizo de mi diálogo pseudo platónico. 
EN “THE DEATH OF SOCRATES" (Gill, 1973, p. 25-28), Gill se ha preguntado sobre la veracidad de la explicación de Platón sobre el juicio y la ejecución de Sócrates. Sócrates fue ejecutado por la cicuta. Al final del Fedón presenta a sus lectores una emotiva descripción de cómo Sócrates toma la cicuta y, después, silenciosa y dignamente, cae dormido y muere, liberando el alma de su cuerpo (Platón, $\mathrm{Fe}$ dón, 116b-118a). El problema es que, si Sócrates fue envenenado por la cicuta, él no hubiera podido morir como lo describe Platón. Los efectos del envenenamiento con Koneion son descritos en la Alexipharmaca de Nicandro (186), y su explicación concuerda con las descripciones halladas en los trabajos de la toxicología moderna. Aparte de la pesadez y entumecimiento mencionada por Platón, los síntomas son: trastorno de la conciencia, asfixia en la garganta, ojos en blanco, nausea, vómito y otros varios efectos desagradables, todos incompatibles con el recuento de Platón. Gill infiere que Platón debe haber distorsionado los hechos y dado una explicación mítica sobre la muerte de su maestro, pero yo no estoy convencido de ello. Si Gill estuviese en lo cierto, la intención de Platón debió haber sido ofrecer una imagen embellecida y heroica de la resistencia de Sócrates, pero, en este punto, debemos recordar que la persona que administra el veneno espera que Sócrates muera, precisamente como Platón describe que él lo hizo (Fedón, 117a-b). En consecuencia, es más improbable que, en el caso de Sócrates, el veneno tuviese un inesperado efecto o que Sócrates, por su autocontrol, hubiera suprimido los síntomas usuales. Es más, de forma previa el diálogo, Platón nos cuenta que el efecto del veneno puede no aparecer si la víctima está muy activa antes de tomar la poción (Fedón, 63d-e), y de acuerdo con ello debe suplementarse la primera dosis con una segunda o, incluso, con una tercera copa. Si Gill estuviese en lo cierto, la víctima simplemente hubiese sido incapaz de tomar una segunda y tercera copa. Gill eleva una interesante y muy importante cuestión, pero ofrece una explicación no plausible. Es, por ejemplo, perfectamente posible asumir que la cicuta estaba combinada con alguna clase de sedante de modo que los síntomas fueran diferentes y que la víctima se volviese inconsciente sin sufrir de asfixia, náusea y otros efectos desagradables. Finalmente, también vale la pena anotar que el recuento de Platón sobre los efectos del envenenamiento con la cicuta encajan con aquellos dados por Jenofonte en su Apología $(7,32)$. 
En Platón (Apol., 23e, 36A), Licón está enlistado como el tercero de los acusadores. De acuerdo con el escolio en 23e, Licón fue Tóricos y el padre de Autólico. Pero en ese caso él debe ser identificado con el Lykon que aparece en el Simposio de Jenofonte y deja al grupo con la exclamación: “iPor Hera, Sócrates, tú pareces ser un verdadero caballero!” (Jenofonte, Symp., 9.1; 1.2, 2.4; 3.12). Según el mismo escolio, él también es idéntico con el Lykon que en, Ar. Vesp. 1301, es yuxtapuesto con Antifón, el líder oligarca, y quien fue acusado de haber traicionado a Naupactos con los espartanos en el año 405 (Metagenes, fragmento 10). El escolio es aceptado por Kirchner (PA, p. 9271), por MacDowell (1962, p. 302) y por Platis (1980). Pero la identificación del acusador de Sócrates con el Lykon de Jenofonte presupone, en el recuento de Jenofonte, una mórbida supresión de un hecho importante conocido por los lectores: una técnica narrativa que, en el caso de Jenofonte, está completamente por fuera de lo común. Por consiguiente, yo sigo a Burnet (1954 p.151) en la negación de tal identificación. La información suministrada en la nota 23 e es, en mi opinión, lo que algunos académicos alemanes denominan acertadamente como "Scholiasten rabulistik". Tenemos información al menos de otros cinco atenienses contemporáneos con el nombre de Lykon (Kirchner, PA. pp, 9267, 9268, 9269, 9273) y la identificación del acusador de Sócrates con uno de aquellos es probable o improbablemente como la identificación de Licón de Tóricos con Lykon de Jenofonte.

Apéndice 4

El oráculo "Ninguno es más sabio que Sócrates" es, en la paráfrasis de Sócrates, tergiversado por la pregunta: “¿A qué se refiere Dios al declarar que soy el más sabio?” Pero de la declaración "nadie es más sabio que Sócrates” es inadmisible deducir que "Sócrates es más sabio que otros" o que "Sócrates es el más sabio (de todos)”. Lógicamente, el oráculo también podría ser tomado con el siguiente significado: "Sócrates es simplemente tan sabio como cualquier otro". En su interpretación del oráculo, Sócrates ha cometido una equivocación lógica, de la cual, en una discusión, él se hubiera aprovechado inmediatamente si la hubiese cometido otra persona. ¿Por qué Platón permite a Sócrates hacer una inferencia falsa? No lo sé, y ninguno de los numerosos comentaristas pareciera haberlo notado. 
Brandwood, L. (1990). The Chronology of Plato's Dialogues. Cambridge: Cambridge University Press.

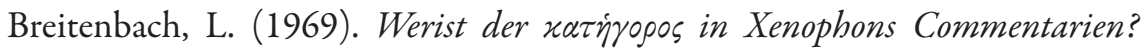
Deutsch: Njbb.

Brickhouse, Th.C. \& Smith, N. (1989). Socrates on Trial. Oxford: Oxford University Press.

Chroust, A.H. (1957). Socrates Man and Myth. The Royal Institute of Philosophy, 35, pp. 372-373.

Cloché, P. (1915). La restauration démocratique à Athènes en 403 avant J.C. Paris: Ernest Leroux Éditeur.

Cobet, C.G. (1858). Novae lectiones. Holanda: Lugduni-Batavorum.

Connor, W.R. (1991). The Other 399, Religion and the Trial of Socrates. Gerogica. Greek Studies in Honour of George Cawkwell. London: University of London, Institute of Classical Studies.

Davies, J.K. (1971). Athenian Propertied Families. Oxford: Oxford University Press.

Derenne, E. (1930). Les proces d'impieté intentés aux philosophes à Athènes au Ve \& au IV esiécles av. J.C. Paris: Sociéte D'édition Les Belles Lettres.

Deubner, L. (1932). Attische Feste. Berlin: Georg Olms Verlagsbuchhandlung Hildesheim.

Develin, R. (1989). Athenian Officials 684-321 B.C. Cambridge: Cambridge University Press.

Dover, K.J. (1976). The Freedom of the Intellectual in Greek Society. Talanta, 7, pp. $24-54$.

Erasmus, S. (1964). Richterzahl und Stimmenverhältniss im Sokrates prozess. Gymnasium, 71, pp. 40-42.

Erbse, H. (1975). Zur Ent stehungszeit von Platos Apologie des Sokrates. RhM, (118), 22-47.

Esquines. (2013). Contra Timarco. (Trad. C.R. Varela). Versión online: https:// archive.org/details/Esquines-contraTimarco-Aeschines-InTimarchus. Recuperado el 19.02 .06 
Fontenrose, J. (1978). The Delphic Oracle. Berkeley: University of California Press.

Gill, Chr. (1973). The Death of Socrates. CQ, 23, pp. 25-28.

Grote, G. (1856). A History of Greece. London: Everyman's library.

Hansen M.H. (1976). Apagoge, Endeixis and Ephegesis against Kakourgoi, Atimoi and Pheugontes. Odense: Odense University Press.

Hansen M.H. (1990). Diokles Law (Dem. 24.42) and the Revision of the Athenian Corpus of Laws in the Archonship of Eukleides. CIMed, 41, 63-71.

Hansen M.H. (1991). The Athenian Democracy in the Age of Demosthenes. Oxford: Oxford University Press.

Hansen, M.H. (1975). Eisangelia. Odense: Odense University Press.

Jacoby, F. (1959). Diagoras óä:sos. Abhandlungen der Deustchen Akademie der Wissenschaften zu Berlin, Kl f. Sprechen, Lit. und Kunst, (3) Berlin.

Kirchner, J. (1901-1903). Prosopographia Attica. Berlin: Berolini, Typis et Impensis Georgil Reimeri.

Lipsius, J.H. (1905-1915). Das attische Recht und Rechtssverfahren I-III. Leipzig: O. R. Reisland.

Loening, Th.C. (1987). The Reconciliation Agreement of 403-402 in Athens Hermes Einzelschriften 53. Wiesbaden: Steiner.

MacDowell, D.M. (1962). Andocides, on the Mysteries. Oxford: Oxford University Press.

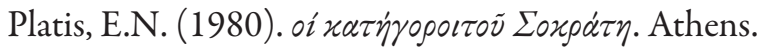

Popper, K.J. (1945). The Open Society and its Enemies. London: Routledge.

Platón. (1985). Apología. Diálogos. (Trad.J. Calogne). Madrid. Editorial Gredos.

Raaflaub, K. (1985). Die Entdeckung der Freiheit. Zur historischen Semantik und Gesellschaftsgeschichtee ines politischen Grundbegriffs der Griechen. Vestigia. Beiträgezuralten Geschichte, (37) (pp. xxvi-347). Munich: Beck.

Ross, D. (1953). Plato's Theory of Ideas. Oxford: Oxford University Press.

Simiterre, R. (1938). La théories ocratique de la vertu-science selon les Memorables de Xonophon. Paris: Téqui.

Stadter, Ph. (1989). A Commentary on Plutarch's Pericles. Chapel Hill: The University of North Carolina Press. 
Stone, I.F. (1989). The Trial of Socrates. Boston: Little, Brown and Company.

Vlastos, G. (1983). The Historical Socrates and the Athenian democracy. Political Theory, 11, pp. 499-516.

Vlastos, G. (1983). Review of E.N. Platis, Socrates Accussers. AJP, 104, pp. 201-206.

Von Arnim, H. (1923). XenophonsMemorabilien und Apologie des Sokrates. København: Kgl. Danske Videnskabernes Selsk. 